\title{
KETIMPANGAN GENDER DALAM PERTUMBUHAN EKONOMI
}

\author{
Erma Aktaria $^{1}$ dan Budiono Sri Handoko ${ }^{1}$ \\ ${ }^{1}$ Magister Ekonomi Pembangunan Universitas Gadjah Mada Yogyakarta \\ Jalan Humaniora, Bulaksumur, Jogjakarta 55281 Indonesia, Telepon: +62-0274-548510 \\ E-mail: budsrih@gmail.com
}

Diterima 16 Maret 2012 / Disetujui 25 Oktober 2012

\begin{abstract}
The objective of this research is to analyze the gender inequality in 14 districts/cities in Central Kalimantan Province by using the Gender Inequality Index (GII), which introduced by UNDP, to analyze the effect of gender inequality with economic growth and compare the use of the GII with the Gender Development Index and Gender Empowerment Measure (GEM) in relation to economic growth. This research uses panel data from 14 districts/cities during 2004-2007, the analytical methods used were descriptive statistics in analyzing gender inequality and statistical inference to explain the influence of gender inequality on economic growth. Descriptive analysis results showed that there are sharp gender inequality in every district/city. The results of regression analysis shows that there are negative and significant effect of gender inequality to economic growth. Gender inequality is statistically represented by a proxy of the GII is not as strong compared to a proxy of the two others.
\end{abstract}

Keywords: gender inequality, economic growth, human development, panel data

\begin{abstract}
Abstrak: Penelitian ini bertujuan menganalisis ketimpangan gender di 14 kabupaten/kota di Provinsi Kalimantan Tengah dengan menggunakan Gender Inequality Index (GII), pengukuran yang diintroduksikan UNDP, untuk menganalisis pengaruh ketimpangan gender terhadap pertumbuhan ekonomi dan membandingkan penggunaaan GII dengan Gender Development Index (GDI) dan Gender Empowerment Measure (GEM) dalam hubungannya dengan pertumbuhan ekonomi. Dengan menggunakan data panel dari 14 kabupaten/kota dengan periode analisis empat tahun (2004-2007), metode yang digunakan adalah statistika deskriptif dalam menganalisis ketimpangan gender dan statistika inferensia untuk menjelaskan pengaruh ketimpangan gender terhadap pertumbuhan ekonomi. Hasil analisis deskriptif menunjukkan ketimpangan gender yang tajam di setiap kabupaten/kota. Hasil analisis regresi menunjukkan pengaruh negatif dan signifikan antara ketimpangan gender dengan pertumbuhan ekonomi. Secara statistik ketimpangan gender yang diwakili proksi GII tidak sekuat proksi dari dua indeks pembangunan gender lain.
\end{abstract}

Kata kunci: ketimpangan gender, pertumbuhan ekonomi, pembangunan manusia, data panel

\section{PENDAHULUAN}

United Nation Development Programme (UNDP) menyatakan dalam Human Development Report bahwa salah satu elemen penting dalam pembangunan manusia adalah pertumbuhan ekonomi yang terdistribusi secara adil baik antargenerasi, antaretnis, antarjenis kelamin, maupun antarwilayah. Salah satu dimensi yang ditekankan oleh UNDP adalah kesetaraan gender. Dimensi ini juga menjadi salah satu komit- men global yang tertuang dalam Millenium Development Goals (MDGs) dalam rangka mencapai kemajuan yang nyata dalam upaya pengentasan kemiskinan.

Dalam mengukur pembangunan gender sebagai salah satu ukuran pembangunan manusia, UNDP mengembangkan Gender Development Index (GDI) dan Gender Empowerment Measure (GEM) melalui Human Develompent Report 1995. Berbagai keterbatasan terhadap penggunaan indeks-indeks tersebut mendorong UNDP memperluas pengukuran dalam mendefinisi- 
kan pembangunan dan ketimpangan gender yang terjadi di berbagai belahan dunia. Melalui Human Development Report 2010, UNDP mengintroduksikan Gender Inequality Index (GII) sebagai alat ukur kuantitatif yang memotret kehilangan pencapaian dalam kehidupan perempuan dalam 3 (tiga) dimensi yaitu kesehatan reproduktif, pemberdayaan, dan pekerjaan.

Kalimantan Tengah adalah salah satu provinsi yang cukup konsisten dalam peringkat 10 (sepuluh) besar pembangunan manusia terbaik secara nasional dalam beberapa tahun terakhir. Namun, hasil Riset Kesehatan Dasar (Riskesdas) tahun 2007 menempatkan Kalimantan Tengah pada posisi ke 22 secara nasional. Hal ini menunjukkan dimensi kesehatan dari Human Development Index (HDI) belum mampu menjelaskan pembangunan dari segi kesehatan dan kurang dapat menunjukkan ketimpangan yang terjadi dalam pembangunan manusia terutama perbedaan antarkelompok gender. Melalui penggunaan GII dengan komposisi dimensi kesehatan yang baru diduga ketimpangan gender dalam proses pembangunan manusia di masing-masing dan antarkabupaten/kota akan semakin tajam dan melebar. Hal ini didasarkan pada tren angka kematian ibu (AKI) di provinsi Kalimantan Tengah mengalami peningkatan selama 4 (empat) tahun terakhir dan tingkat fertilitas remaja yang cukup tinggi yaitu 65 per 1000 wanita dengan golongan usia sama pada tahun 2000 yang berada pada peringkat ketiga tertinggi di Indonesia (www.datastatistikindonesia.com).

Berdasarkan uraian di atas maka permasalahan utama dalam penelitian ini adalah indeks pembangunan gender yang ada belum mampu menjelaskan pembangunan manusia khususnya ketimpangan gender secara menyeluruh, sehingga perlu pengembangan Gender Inequality Index (GII) dalam menganalisis ketimpangan gender dan pengaruhnya terhadap pertumbuhan ekonomi di 14 (empat belas) kabupaten/kota di Provinsi Kalimantan Tengah.

Berdasarkan latar belakang dan permasalahan yang dikemukakan maka tujuan yang ingin dicapai dari penelitian ini antara lain menganalisis ketimpangan gender dengan menggunakan Gender Inequality Index (GII) dan menganalisis pengaruh ketimpangan gender terhadap pertumbuhan ekonomi di provinsi Kalimantan Tengah.

Ketimpangan gender dalam hubungannya dengan pertumbuhan ekonomi di berbagai negara telah banyak menjadi objek penelitian para ahli. Martin dan Garvi (2009) mengemukakan pertumbuhan GDP menstimulasi peningkatan nilai GDI dan HDI serta menurunkan kesenjangan antarkedua indeks tersebut. Dalam penelitian lainnya, Klasen dan Lamanna (2009) menghitung konsekuensi secara kuantitatif yang harus ditanggung oleh sebuah negara ketika terdapat ketimpangan gender dalam pendidikan dan pekerjaan dinegaranya yaitu perbedaan laju pertumbuhan ekonomi berkisar antara 0,9-1,7 persen di Timur Tengah dan Afrika Utara dan 0,1-1,6 persen di Asia Selatan bila dibandingkan dengan negara-negara di kawasan Asia Timur dan Pasifik. Di Indonesia, keterkaitan antara kesetaraan gender secara statistik menunjukkan pengaruh yang signifikan dan negatif terhadap kemiskinan dan positif terhadap pertumbuhan ekonomi (Samosir \& Toersilaningsih, 2004).

Beberapa argumentasi yang menguatkan mengapa ketimpangan gender dalam pemenuhan akses kebutuhan dasar dapat berdampak negatif bagi pertumbuhan ekonomi (Seguino, 2008), antara lain sebagai berikut:

(1) Kesenjangan gender dalam pendidikan akan mengurangi jumlah rata-rata modal manusia dalam masyarakat. Kesenjangan ini menghalangi bakat-bakat yang memiliki kualifikasi tinggi yang terdapat pada anak perempuan yang pada akhirnya akan mengurangi tingkat pengembalian investasi sektor pendidikan (marginal returns of education). Hal ini terbukti dari berbagai studi yang menyatakan bahwa tingkat pengembalian investasi pendidikan pada anak perempuan lebih baik dibandingkan pada anak laki-laki. Mengurangi kesenjangan gender dalam akses pendidikan secara keseluruhan akan meningkatkan pembangunan ekonomi.

(2) Adanya eksternalitas dari pendidikan kaum wanita bagi penurunan tingkat fertilitas, tingkat kematian anak, dan mendorong pendidikan yang lebih baik bagi generasi mendatang. 
Penurunan fertilitas memberikan eksternalitas positif bagi penurunan angka beban ketergantungan dalam angkatan kerja.

(3) Pemerataan kesempatan dalam sektor pendidikan dan pekerjaan bagi setiap gender memberikan dampak positif bagi kemampuan bersaing suatu negara dalam perdagangan internasional.

(4) Bekal pendidikan dan kesempatan kerja di sektor formal yang lebih besar bagi kaum wanita akan meningkatkan bargaining power mereka dalam keluarga. Hal ini penting karena terdapat perbedaan pola antara perempuan dan laki-laki dalam perilaku menabung dan investasi ekonomi baik non ekonomi seperti kesehatan dan pendidikan anak yang akan meningkatkan modal manusia generasi mendatang dan pada akhirnya mendorong pertumbuhan ekonomi.

(5) Beberapa penelitian menunjukkan bahwa pekerja wanita memiliki kecenderungan kecil untuk melakukan tindak korupsi dan nepotisme dibandingkan pekerja pria. Walaupun begitu, argumen ini masih perlu dibuktikan lebih lanjut secara empiris.

Dalam literatur lain, Todaro dan Smith (2006) menambahkan bahwa kaum wanita memikul beban terbesar dari kemiskinan dan kelangkaan sumberdaya (lahan garapan, modal, dan lain-lain), maka perbaikan yang signifikan dalam peran dan status wanita dalam baik dalam pendidikan maupun kesehatan memiliki dampak penting dalam memutuskan lingkaran setan kemiskinan.

Sebelum tahun 2010, ukuran pembangunan gender yang secara luas dipergunakan adalah GDI dan GEM yang diperkenalkan oleh UNDP pada tahun 1995. GDI merupakan variasi HDI yang disagregasi menurut jenis kelamin. Variabel-variabel yang membentuk GDI adalah merupakan variabel HDI yang dikhususkan pada pencapaian kaum perempuan yaitu angka harapan hidup, pendidikan dan pendapatan per kapita (PPP). Sedangkan GEM lebih memfokuskan pencapaian perempuan dalam lingkup sosial ekonomi dan politik. GEM secara eksplisit mengukur aktivitas pemberdayaan perempuan dalam politik, pemerintahan dan kegiatan ekonomi.

Kiriti dan Tisdell (2003) mengemukakan kelemahan utama dari dua indeks di atas adalah nilai agregat yang tidak secara tajam menunjukkan ketimpangan gender yang terjadi. Indeks ini juga mengkombinasikan pengukuran absolut dengan pencapaian relatif. UNDP (2010) menyebutkan bahwa di beberapa kasus ada negara dengan pendapatan absolut rendah namun kesetaraan gender yang baik dikategorikan dalam kelompok pembangunan manusia rendah. Selain itu, keterbatasan data terutama data pendapatan menyebabkan kedua indeks ini sering mengalami penyesuaian sehingga menjadi sulit mengkomparasi dengan nilai indeks negara lain. Menyadari kelemahan ini, UNDP dalam publikasi Human Development Report 2010 kemudian mengembangkan indeks

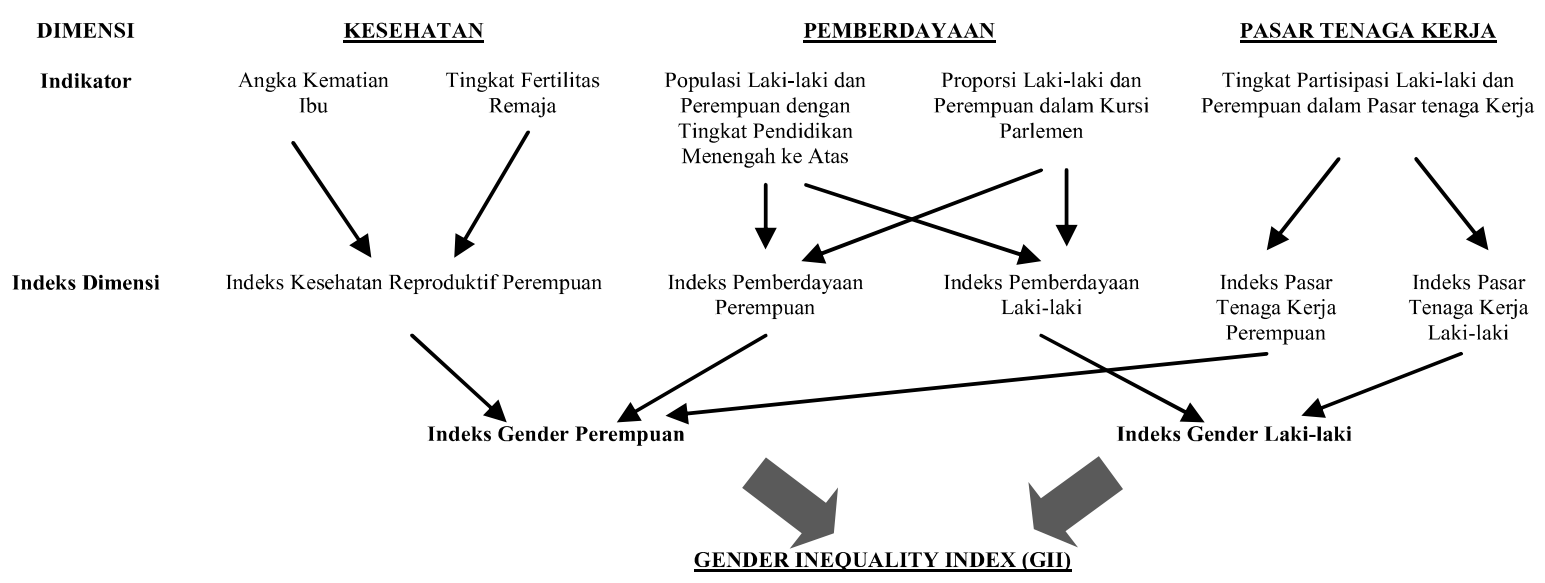

Sumber: UNDP - Human Development Report 2010

Gambar 1. Dimensi Gender Inequality Index (GII) secara Grafis 
ketimpangan gender yang diperluas yaitu Gender Inequality Index (GII). Dimensi GII secara grafis ditunjukkan oleh Gambar 1.

Indeks yang dihasilkan memotret hilangnya pencapaian dalam tiga dimensi kunci di atas akibat adanya ketimpangan gender yang berkisar antara 0 dan 1 . Semakin mendekati angka nol berarti semakin mencapai kesetaraan gender, sebaliknya semakin mendekati angka 1 maka diinterpretasikan telah terjadi ketimpangan gender di wilayah tersebut.

\section{METODE PENELITIAN}

\section{Analisis Ketimpangan Gender}

Pengukuran ketimpangan gender menggunakan data sekunder dari 14 (empat belas) kabupaten/kota di provinsi Kalimantan Tengah selama periode analisis tahun 2004-2007. Analisis ketimpangan gender dilakukan menggunakan statistik deskriptif. Analisis juga meliputi perbandingan secara deskriptif antarindeks ketimpangan gender yaitu GII yang dikonstruksi dalam penelitian ini, GII yang diproksi dari perbandingan HDI dan GDI, dan GII yang diproksi dari perbandingan antara HDI dan GEM.

\section{Analisis Pengaruh Ketimpangan Gender terhadap Pertumbuhan Ekonomi}

Pengaruh ketimpangan gender terhadap pertumbuhan ekonomi dianalisis dengan metode regresi menggunakan datapanel. Data panel gabungan dua jenis data yaitu time series dan cross-section dianggap mampu mengatasi masalah kurangnya unit observasi dan gangguangangguan klasik yang menyebabkan parameter regresi menjadi bias (Insukindro dkk, 2001). Menurut Widarjono (2009), tiga pendekatan umum yang digunakan dalam mengestimasi data panel adalah pendekatan common effect, fixed effect, dan random effect. Pendekatan common effect yang memperlakukan koefisien intercept dan slope tetap antarwaktu dan unit analisis sangat jarang terjadi dalam dunia nyata. Berdasarkan hal tersebut, maka dalam penelitian ini dua pendekatan yang akan dibandingkan adalah fixed effect dan random effect saja. Pendekatan terbaik dipilih melalui uji formal yaitu
Hausman test.

Berdasarkan hasil regresi data panel dengan pendekatan terbaik kemudian dilakukan uji signifikansi untuk menentukan apakah hipotesa yang dibangun dalam penelitian ini dapat diterima atau tidak. Uji signifikansi tersebut antara lain uji koefisien determinasi yang disesuaikan (adjusted $R^{2}$ ), uji signifikansi F, uji signifikansi t, dan uji asumsi klasik.

Dalam menjelaskan pengaruh ketimpangan gender terhadap pertumbuhan ekonomi, penelitian ini menggunakan tiga jenis variabel sebagai proksi ketimpangan gender, antara lain.

(1) Gender Inequality Index* $\left(G I I^{*}\right)$, dengan metode perhitungan sebagaimana yang direkomendasikan oleh UNDP dalam Human Development Report 2010. Tanda bintang superscript $\left({ }^{*}\right)$ menunjukkan indeks ini telah mengalami penyesuaian dalam dimensi kesehatan reproduktif dan pemberdayaan pendidikan perempuan.

(2) Gender Inequality Index ${ }^{* *}\left(G I I^{* *}\right)$, merupakan indeks ketimpangan gender yang di dapatkan melalui perbandingan nilai HDI dengan GDI.

(3) Gender Inequality Index ${ }^{* * *}\left(G I I^{* * *}\right)$, merupakan indeks ketimpangan gender yang diperoleh melalui perbandingan antara HDI dengan GEM.

Sedangkan variabel pertumbuhan ekonomi diproksi dari nilai Produk Domestik Regional Bruto (PDRB) atas dasar harga konstan. Variabel penjelas lain adalah jumlah anggaran belanja APBD bidang kesehatan (BKSH1) dan pendidikan (BDIK1) sebagai proksi kebijakan pemerintah serta variabel rasio dependensi (DPR) sebagai pendekatan pertumbuhan populasi penduduk.

\section{HASIL DAN PEMBAHASAN}

\section{Analisis Ketimpangan Gender}

Variabel Gender Inequality Index* (GII*) yang dikonstruksi dalam penelitian ini juga mengalami penyesuaian karena ketidaktersediaan data di lapangan. Indikator-indikator yang mengalami penyesuaian adalah tingkat fertilitas remaja menjadi tingkat fertilitas umum dan tingkat pendidikan yang ditamatkan penduduk 
Tabel 1. Gender Inequality Index* $\left(G I^{*}\right)$ di 14 Kabupaten/Kota di Provinsi Kalimantan Tengah, 2004 - 2007

\begin{tabular}{lccccc}
\hline \multirow{2}{*}{ Kabupaten/Kota } & \multicolumn{2}{c}{ GI $^{*} \mathbf{( \% )}$} & \multirow{2}{*}{ Rata-Rata } \\
\cline { 2 - 4 } & $\mathbf{2 0 0 4}$ & $\mathbf{2 0 0 5}$ & $\mathbf{2 0 0 6}$ & $\mathbf{2 0 0 7}$ & 64,6 \\
Kobar & 65,2 & 64,5 & 63,9 & 64,6 & 68,7 \\
Kotim & 71,2 & 69,0 & 68,7 & 65,8 & 62,4 \\
Kapuas & 63,4 & 60,4 & 64,9 & 61,0 & 65,8 \\
Barsel & 67,3 & 66,6 & 62,3 & 67,0 & 59,0 \\
Barut & 60,5 & 52,3 & 63,6 & 59,7 & 72,0 \\
Sukamara & 76,0 & 72,2 & 71,8 & 68,0 & 71,9 \\
Lamandau & 66,2 & 74,3 & 72,7 & 74,3 & 78,4 \\
Seruyan & 80,8 & 79,8 & 78,9 & 74,3 & 72,2 \\
Katingan & 72,1 & 71,1 & 69,9 & 75,8 & 64,2 \\
Pulang Pisau & 66,0 & 63,1 & 64,5 & 63,4 & 57,8 \\
Gunung Mas & 63,5 & 63,6 & 52,7 & 51,6 & 66,9 \\
Barito Timur & 63,6 & 71,8 & 63,7 & 68,6 & 69,0 \\
Murung Raya & 69,8 & 74,7 & 71,1 & 60,5 & 59,8 \\
Palangka Raya & 66,1 & 58,1 & 58,7 & 56,4 & \\
\hline
\end{tabular}

usia $\geq 25$ tahun diperluas menjadi penduduk usia $\geq 10$ tahun.

Tabel 1 menunjukkan hasil perhitungan GII* dari 14 (empat belas) kabupaten/kota di provinsi Kalimantan Tengah selama tahun 2004 sampai dengan 2007. Pencapaian rata-rata selama periode analisis berkisar antara 57,8-78,4 persen. Seluruh kabupaten/kota menunjukkan nilai $G I^{*}$ di atas 50 persen. Hal ini berarti terdapat ketimpangan gender yang tajam di dalam daerah masing-masing. Daerah yang memiliki ketimpangan gender terparah adalah kabupaten Seruyan, Katingan, Sukamara, dan Lamandau. Keempat kabupaten yang merupakan kabupaten pemekaran ini memiliki indeks GII* di atas 70 persen. Daerah dengan nilai $G I^{*}$ terendah adalah kabupaten Gunung Mas, Barito Utara dan Kota Palangka Raya.

Secara umum, kisaran angka tersebut masih sangat jauh dari kesetaraan yaitu 0 persen. Hal ini berarti masih terdapat ketimpangan gender yang cukup tajam dalam kabupaten/kota di provinsi Kalimantan Tengah. Secara implisit menunjukkan bahwa pembangunan yang telah dilaksanakan belum mampu mengangkat peran dan status perempuan di provinsi Kalimantan Tengah dalam mencapai kesetaraan antargender. Hal ini memperkuat pernyataan Megawangi (2005) bahwa kesetaraan gender sempurna di Indonesia masih sangat sulit untuk direalisasikan karena terkait masalah kultur dan kebiasaan.

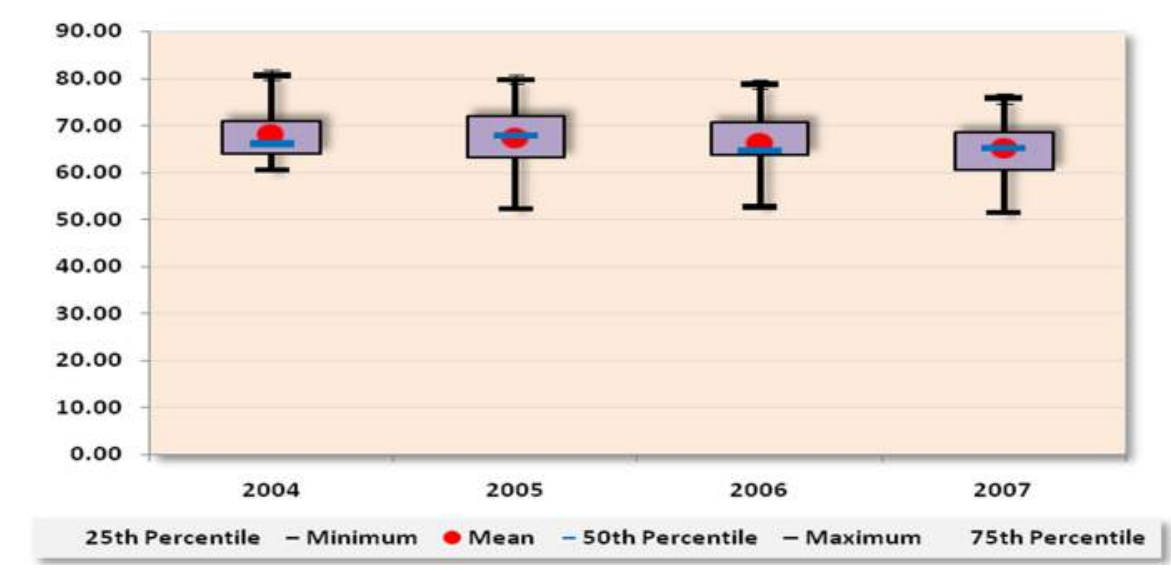

Gambar 2. Ketimpangan Gender dengan Indikator $G I^{*}$ di 14 Kabupaten/ Kota di Provinsi Kalimantan Tengah, 2004 - 2007 
Apakah terjadi ketimpangan gender antarkabupaten/kota? Diagram boxplot pada Gambar 2 menunjukkan sebaran data $G I^{*}$ antarkabupaten/kota di provinsi Kalimantan Tengah selama periode analisis. Berdasarkan sebaran data tersebut dapat dilihat rata-rata $G I I^{*}$ dari tahun ke tahun tidak mengalami perubahan berarti. Hal ini menguatkan pernyataan sebelumnya bahwa pembangunan yang dilaksanakan di kabupaten/kota di provinsi Kalimantan Tengah belum sepenuhnya mengarusutamakan gender seperti yang diamanahkan Instruksi Presiden Nomor 9 Tahun 2000 tentang pengarusutamaan gender dalam pembangunan nasional. Bagian box dari diagram boxplot dari tahun ke tahun memiliki besar yang hampir sama sehingga dapat diinterpretasikan jika sebaran nilai GII* antarkabupaten/kota hampir merata dan tidak banyak berubah dari tahun ke tahun. Panjang whiskers boxplot sepanjang periode analisis juga menunjukkan terjadi penurunan rentang nilai maksimum dan minimum walaupun hanya sedikit. Berdasarkan gambaran tersebut, dapat disimpulkan bahwa ketimpangan gender melalui ukuran $G I^{*}$ cukup merata antarkabupaten/kota di wilayah provinsi Kalimantan Tengah selama tahun 20042007. Namun, ketimpangan dalam kabupaten/ kota sendiri masih sangat tajam. Rata-rata Indeks GII* provinsi Kalimantan Tengah yang dikonstruksi dalam penelitian ini yaitu sebesar
66,63 persen masih sedikit lebih baik daripada rata-rata GII Indonesia yang dirilis oleh Human Development Report 2010 yaitu peringkat 100 dengan skor 68,0 persen (dinyatakan dalam persen) pada tahun 2008.

Variabel ketimpangan gender yaitu GII** dan $G I^{* * *}$ merupakan variabel yang dikonstruksi dari indeks pembangunan gender yang telah secara luas digunakan sejak tahun 1995 dan diadopsi oleh banyak negara yaitu GDI untuk GII** dan GEM untuk GII*** Pembentukan dua variabel ini menggunakan formula yang digunakan oleh Martin dan Garvi (2009) dan dikonstruksi karena GDI dan GEM sendiri belum menunjukkan ketimpangan gender yang terjadi dalam wilayah geografi yang spesifik.

GII** mengukur kehilangan pembangunan manusia pada tiga dimensi HDI akibat adanya ketimpangan gender. Tabel 2 menunjukkan nilai GII** di 14 (empat belas) kabupaten/kota di Kalimantan Tengah selama tahun 2004 sampai dengan 2007. Rata-rata pencapaian selama periode analisis berkisar antara 3,27 - 37,66 persen dengan kabupaten Sukamara, Seruyan dan Pulang Pisau sebagai kabupaten dengan angka rata-rata tertinggi atau dikatakan mengalami ketimpangan gender terbesar dan kehilangan capaian pembangunan terbesar.

Secara umum, adanya kecenderungan penurunan ketimpangan gender di masing-masing daerah selama periode analisis. Pada awal

Tabel 2. Gender Inequality Index ${ }^{* *}\left(G^{* *}\right)$ di 14 Kabupaten/Kota di provinsi Kalimantan Tengah, $2004-2007$

\begin{tabular}{lrrrrr}
\hline \multirow{2}{*}{ Kabupaten/Kota } & \multicolumn{3}{c}{ GII** (\%) } & \multirow{2}{*}{ Rata-Rata } \\
\cline { 2 - 4 } & $\mathbf{2 0 0 4}$ & $\mathbf{2 0 0 5}$ & $\mathbf{2 0 0 6}$ & $\mathbf{2 0 0 7}$ & 19,43 \\
Kobar & 21,74 & 19,83 & 19,75 & 16,41 & 19,95 \\
Kotim & 23,92 & 24,55 & 17,06 & 14,27 & 16,37 \\
Kapuas & 19,21 & 18,94 & 13,99 & 13,34 & 8,43 \\
Barsel & 11,76 & 12,48 & 4,97 & 4,49 & 3,27 \\
Barut & 5,79 & 5,22 & 1,62 & 0,43 & 37,66 \\
Sukamara & 48,27 & 48,43 & 28,84 & 25,12 & 18,54 \\
Lamandau & 21,29 & 19,94 & 17,07 & 15,85 & 24,08 \\
Seruyan & 32,39 & 31,88 & 18,49 & 13,57 & 14,89 \\
Katingan & 16,05 & 16,83 & 15,38 & 11,30 & 27,95 \\
Pulang Pisau & 34,31 & 33,04 & 23,18 & 21,26 & 5,70 \\
Gunung Mas & 9,00 & 8,95 & 2,63 & 2,21 & 5,83 \\
Barito Timur & 8,92 & 9,42 & 2,79 & 2,18 & 17,85 \\
Murung Raya & 22,03 & 22,96 & 14,11 & 12,31 & 12,83 \\
Palangka Raya & 15,71 & 14,94 & 10,64 & 10,03 & 12,83 \\
\hline
\end{tabular}

Sumber: www.kemenegpp.go.id 


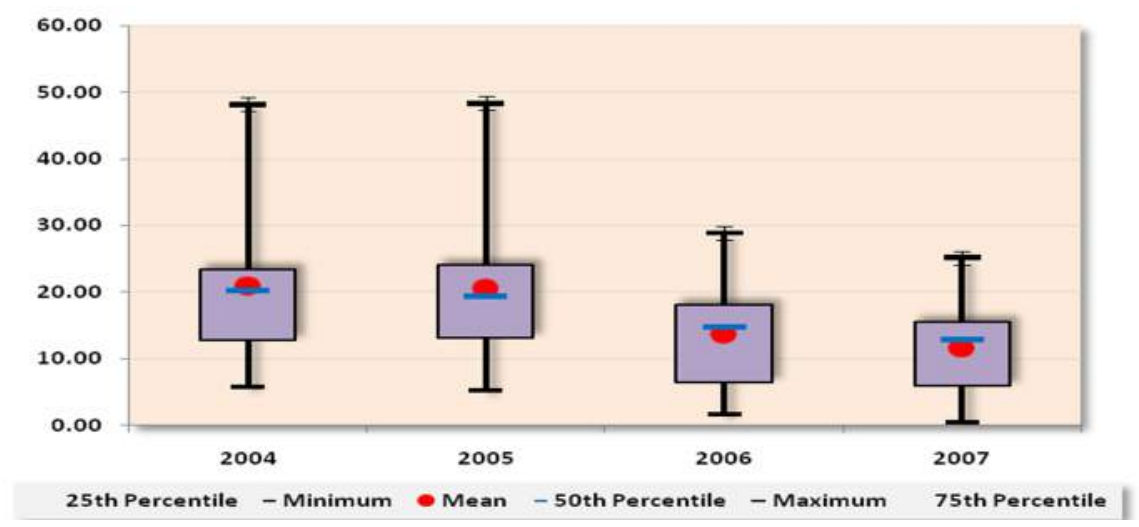

Gambar 3. Ketimpangan Gender dengan Indikator GII** di 14 Kabupaten/ Kota di Provinsi Kalimantan Tengah, 2004 - 2007

periode, kehilangan terbesar dialami oleh kabupaten Sukamara, Seruyan dan Pulang Pisau. Kabupaten Seruyan khususnya pada tahun 2006 berhasil mengkonvergensikan diri dengan kabupaten lainnya dimana terjadi penurunan ketimpangan yang cukup drastis. Penurunan ketimpangan berdasarkan $G I I^{* *}$ di kabupatenkabupaten tersebut berkisar antara 13,05 poin 23,15 poin. Hal ini sejalan dengan penemuan Martin dan Garvi (2009) bahwa peningkatan nilai $G D I(g)$ terbesar justru dialami oleh daerahdaerah dengan pencapaian awal yang lebih rendah ketika menganalisis konvergensi nilai GDI $(g)$ di Spanyol. Daerah dengan kehilangan pembangunan manusia yang cukup rendah adalah kabupaten Barito Utara, Gunung Mas dan Barito Timur.

Berdasarkan Gambar 3, rata-rata nilai GII** selama periode analisis di Kalimantan Tengah cenderung mengalami penurunan. Perbedaan antara pencapaian maksimum dan minimum semakin berkurang dari tahun ke tahun (lihat garis whiskers). Tinggi box pada Diagram 3 tidak menunjukkan perubahan berarti selama periode analisis yang berarti ketimpangan gender dengan indeks GII** antarkabupaten/kota tidak berbeda tajam dan persebaran data cenderung konstan antartahun. Posisi diagram boxplot yang mendekati garis horizontal menunjukkan ketimpangan yang cukup rendah dan lebih dekat dengan kesetaraan.

Secara umum, indeks ketimpangan ini diyakini kurang dapat menggambarkan kehilangan yang sebenarnya terjadi. Nilai GII** yang cenderung kecil mendekati kesetaraan secara riil sangat sulit ditemukan di lapangan. Kiriti dan Tisdell (2003) mengkritisi GDI yang merupakan core dari perhitungan $G I^{* *}$ ini. GDI merupakan indeks yang sangat sensitif, terlalu banyak mengalami penyesuaian dan kurang dapat menggambarkan ketimpangan gender yang sebenarnya.

Nilai GII*** menggambarkan kehilangan dalam pembangunan manusia dalam dimensi lain yaitu dimensi partisipasi dan peran perempuan dalam dunia politik, pengambilan keputusan dan tenaga kerja akibat adanya ketimpangan gender. Tabel 3 menunjukkan adanya ketimpangan yang lebih besar dibandingkan $G I I^{* *}$. Ketimpangan terbesar dialami oleh Kabupaten Sukamara, Lamandau, Seruyan.

Ketimpangan terbesar dialami oleh kabupaten Sukamara, Lamandau, dan Seruyan dengan rata-rata selama periode analisis berturutturut 64,14 persen, 40,58 persen dan 61,38 persen. Hal yang cukup mengejutkan adalah ketimpangan yang cukup tinggi dialami Kota Palangka Raya sebagai ibukota provinsi. Penurunan nilai $G I I^{* * *}$, yang berarti menuju kesetaraan, selama periode analisis berkisar antara 0,58-33,66 poin. Sebagaimana halnya $\mathrm{GII}^{* *}$, penurunan GII $^{* * *}$ terbesar dialami oleh kabupaten-kabupaten dengan pencapaian awal GEM rendah atau pencapaian awal GI ${ }^{* * *}$ tinggi atau dengan kata lain mengalami ketimpangan yang cukup tinggi yaitu kabupaten Sukamara $(24,03$ poin), Lamandau (33,66 poin), dan Pulang Pisau (26, 4 poin). 
Tabel 3. Gender Inequality Index ${ }^{* * *}\left(G I I^{* * *}\right)$ di 14 Kabupaten/Kota di Provinsi Kalimantan Tengah, $2004-2007$

\begin{tabular}{lccccc}
\hline \multirow{2}{*}{ Kabupaten/Kota } & \multicolumn{4}{c}{$G I^{* * *}(\%)$} & \multirow{2}{*}{ Rata-rata } \\
\cline { 2 - 4 } & $\mathbf{2 0 0 4}$ & $\mathbf{2 0 0 5}$ & $\mathbf{2 0 0 6}$ & $\mathbf{2 0 0 7}$ & 23,34 \\
Kobar & 29,17 & 23,04 & 21,97 & 19,18 & 35,91 \\
Kotim & 41,54 & 39,72 & 32,46 & 29,90 & 15,81 \\
Kapuas & 18,93 & 18,25 & 13,02 & 13,06 & 15,23 \\
Barsel & 18,84 & 19,21 & 11,60 & 11,25 & 20,38 \\
Barut & 26,58 & 19,64 & 17,59 & 17,70 & 64,14 \\
Sukamara & 77,75 & 66,29 & 58,81 & 53,72 & 40,58 \\
Lamandau & 64,89 & 35,19 & 31,03 & 31,23 & 61,38 \\
Seruyan & 64,91 & 67,42 & 59,38 & 53,78 & 34,90 \\
Katingan & 33,66 & 40,81 & 33,99 & 31,14 & 40,16 \\
Pulang Pisau & 56,93 & 41,85 & 31,33 & 30,53 & 16,88 \\
Gunung Mas & 16,74 & 17,90 & 16,74 & 16,16 & 21,63 \\
Barito Timur & 24,17 & 25,96 & 18,44 & 17,95 & 17,76 \\
Murung Raya & 24,46 & 23,80 & 12,99 & 9,80 & 36,76 \\
Palangka Raya & 40,31 & 38,83 & 34,24 & 33,65 & \\
\hline
\end{tabular}

Gambar 4 menunjukkan persebaran data GII $^{* * *}$ selama periode analisis. Secara umum, terdapat kecenderungan penurunan nilai ratarata $G I I^{* * *}$ yang berarti terdapat perbaikan peran sosial, politik dan ekonomi wanita di wilayah Kalimantan Tengah. Persebaran data pun semakin seragam sebagaimana halnya yang ditunjukkan oleh lebar box yang semakin tipis pada diagram boxplot. Hal ini menunjukkan ada kecenderungan terjadinya penurunan ketimpangan gender antarkabupaten/kota dalam dimensi pemberdayaan. Rentang perbedaan antardaerah pun semakin menurun seperti ditunjukkan oleh garis whisker yang semakin memendek.
Walaupun cenderung mengalami penurunan, namun angka GII*** yang cukup tinggi (menjauhi garis horizontal) menunjukkan bahwa peran perempuan dalam bidang sosial, politik dan ekonomi di wilayah Kalimantan Tengah masih sangat minim. Badan Pemberdayaan Perempuan, Anak dan Keluarga Berencana provinsi Kalimantan Tengah (2009) menyatakan bahwa hampir di semua lembaga legislatif kabupaten/kota belum memenuhi kuota 30 persen wakil rakyat bergender perempuan kecuali kabupaten Gunung Mas yang mencapai 35 persen hasil pemilihan umum legislatif tahun 2009. Pada level eksekutif, proporsi pengambil keputusan yang dipegang oleh perem-

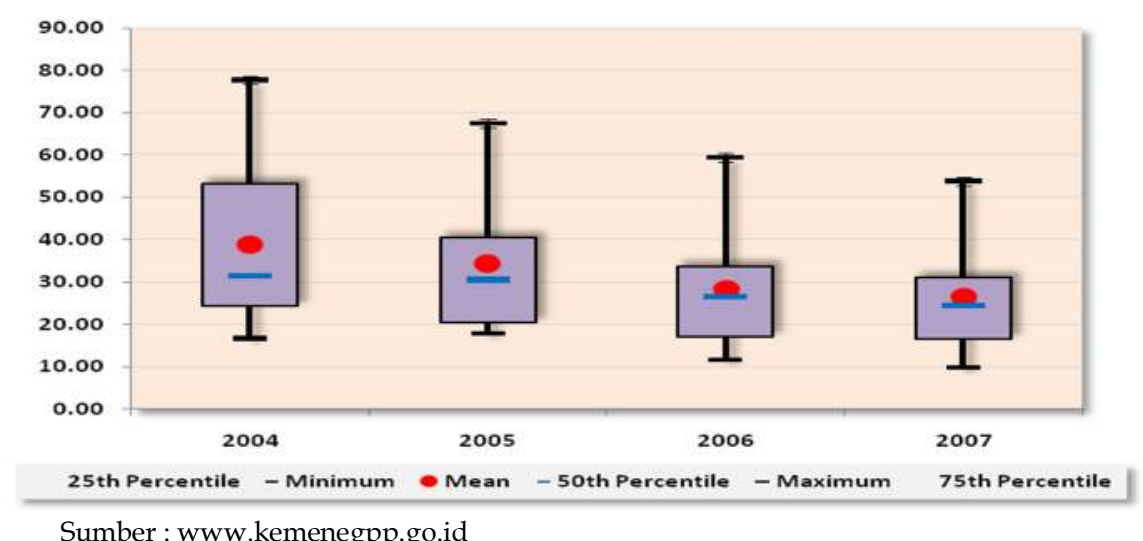

Gambar 4. Ketimpangan Gender dengan Indikator GII*** di 14 Kabupaten/ Kota di Provinsi Kalimantan Tengah, 2004 - 2007 


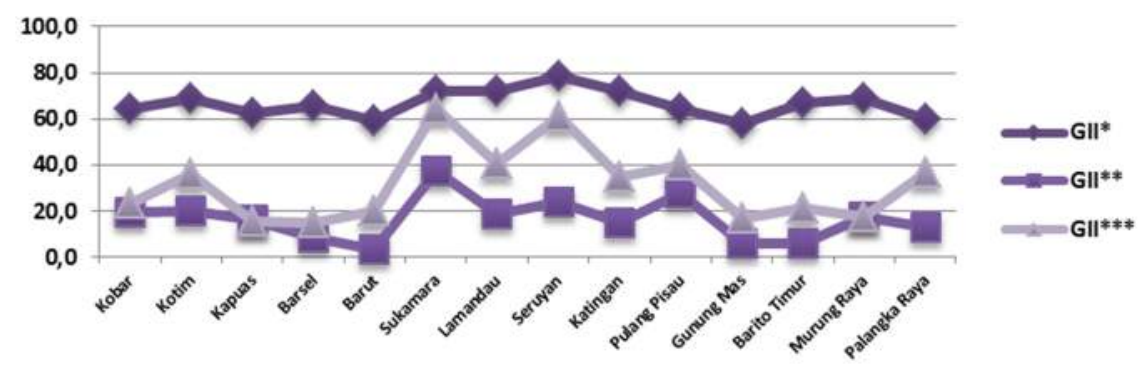

Gambar 5. Perbandingan Rata-rata Ketimpangan Gender dengan Indikator $G I^{*}$, GII** dan GII $^{* * *}$ di 14 Kabupaten/Kota di Provinsi Kalimantan Tengah, 2004 - 2007

puan sekitar 40,5 persen pada tahun 2009.

Gambar 5 menunjukkan perbandingan antara rata-rata $G I^{*}$ dengan $G I I^{* *}$ yang merupakan representasi dari GDI dan GII*** representasi dari GEM, terlihat jelas indikator $G I^{*}$ lebih unggul dalam memotret ketimpangan yang terjadi di Kalimantan Tengah. Nilai GII* kabupaten/kota sebagian besar masih mendekati ketimpangan dibandingkan GDI dan GEM yang hampir mendekati kesetaraan. Secara deskriptif dapat disimpulkan GII* lebih mampu menggambarkan kondisi ketimpangan gender di wilayah provinsi Kalimantan Tengah. Hasil perhitungan dengan menggunakan ketiga indeks ini menunjukkan adanya konsistensi antarindeks dalam menjelaskan wilayah yang paling parah mengalami ketimpangan gender. Wilayah tersebut antara lain kabupaten Sukamara dan Seruyan.

\section{Analisis Pengaruh Ketimpangan Gender Terhadap Pertumbuhan Ekonomi}

Dalam penelitian ini, pengaruh ketimpangan gender terhadap pertumbuhan ekonomi akan dilihat melalui pengaruh ketiga jenis indeks ketimpangan gender di atas dengan metode regresi panel data, dengan spesifikasi model sebagai berikut.

Tabel 4. Model Persamaan Regresi Data Panel

\begin{tabular}{|c|c|}
\hline Model & Spesifikasi \\
\hline $\begin{array}{c}\text { Model } \\
1\end{array}$ & $\begin{array}{l}\operatorname{LnPDRB}_{i t}=a_{0}+a_{1} \operatorname{LnGII}_{i t}+a_{2} \operatorname{LnBKSH}_{i t} \\
+a_{3} \operatorname{LnBDIK}_{i t}+a_{4} \operatorname{LnDPR}_{i t}+\varepsilon_{i t}\end{array}$ \\
\hline $\begin{array}{l}\text { Model } \\
2\end{array}$ & $\begin{array}{l}\text { Ln PDRB } \\
+\beta_{3} \operatorname{LnBDIK}_{i t}+\beta_{4}+\beta_{1} \operatorname{LnGII}^{* *}{ }_{i t}+\beta_{2} \operatorname{LnBKS}_{i t}+\varepsilon_{i t}\end{array}$ \\
\hline $\begin{array}{c}\text { Model } \\
3\end{array}$ & $\begin{array}{l}\operatorname{LnPDRB}_{i t}=\gamma_{0}+\gamma_{1} \operatorname{LnGII}^{* * *}{ }_{i t}+\gamma_{2} \\
\operatorname{LnBKSH}_{i t}+\gamma_{3} \operatorname{LnBDIK}_{i t}+\gamma_{4} \operatorname{LnDPR}_{i t}+\varepsilon_{i t}\end{array}$ \\
\hline
\end{tabular}

Tujuan utama menggunakan model dengan variabel indeks ketimpangan gender yang berbeda adalah untuk melihat indeks ketimpangan gender mana yang paling berpengaruh terhadap pertumbuhan ekonomi di provinsi Kalimantan Tengah selama periode analisis. Sedangkan variabel penjelas lain adalah variabel yang pernah digunakan dalam penelitian lain dan menunjukkan hasil yang signifikan.

Pendekatan regresi data panel yang digunakan dalam penelitian ini adalah pendekatan fixed effect dan random effect. Metode terbaik di antara kedua pendekatan ini dapat ditentukan dengan pengujian formal yaitu uji Hausman (Widarjono, 2009). Hasil uji Hausman atas hasil estimasi model 1, 2, dan 3 dengan menggunakan software analisis ekonometrika E-Views versi 6 dirangkum dalam Tabel 5 .

Tabel 5. Hasil Uji Hausman untuk Menentukan Pendekatan Terbaik Antara Fixed Effect dan Random Effect pada Estimasi Model 1, 2 , dan 3

\begin{tabular}{cccc}
\hline Model & $\begin{array}{c}\text { Chi-Square } \\
\text { Statistik }\end{array}$ & Probabilitas & Kesimpulan \\
\hline $\begin{array}{c}\text { Model } \\
1\end{array}$ & 27.581436 & 0.0000 & Fixed Effect \\
$\begin{array}{c}\text { Model } \\
2\end{array}$ & 22.575594 & 0.0002 & Fixed Effect \\
$\begin{array}{c}\text { Model } \\
3\end{array}$ & 18.751972 & 0.0009 & Fixed Effect \\
\hline
\end{tabular}

Berdasarkan Tabel 5 maka pendekatan terbaik dalam mengestimasi pengaruh ketimpangan gender terhadap pertumbuhan ekonomi pada tiga jenis model regresi dalam penelitian ini adalah pendekatan fixed effect. Hasil estimasi untuk ketiga model persamaan dengan pende- 
Tabel 6. Hasil Estimasi dengan Pendekatan Fixed Effect

\begin{tabular}{|c|c|c|c|c|c|c|c|c|c|c|c|c|}
\hline \multirow{2}{*}{ Parameter } & \multicolumn{4}{|c|}{ Model $1\left(G I I^{*}\right)$} & \multicolumn{4}{|c|}{ Model $2\left(G I^{* *}\right)$} & \multicolumn{4}{|c|}{ Model $3\left(G I I^{* * *}\right)$} \\
\hline & Koef. & $\begin{array}{c}\text { Std. } \\
\text { Error }\end{array}$ & $\begin{array}{c}t- \\
\text { Stat. }\end{array}$ & Prob & Koef. & $\begin{array}{l}\text { Std. } \\
\text { Error }\end{array}$ & t-Stat. & Prob & Koef. & $\begin{array}{c}\text { Std. } \\
\text { Error }\end{array}$ & t-Stat. & Prob \\
\hline Konstanta & 13,754 & 0,171 & 80,589 & 0,000 & 13,308 & 0,096 & 138,233 & 0,000 & 13,554 & 0,093 & 145,846 & 0,000 \\
\hline Ln GII & $-0,284$ & 0,156 & $-1,822$ & 0,076 & $-0,067$ & 0,012 & $-5,742$ & 0,000 & $-0,148$ & 0,026 & $-5,607$ & 0,000 \\
\hline Ln BKSH1 & 0,061 & 0,023 & 2,611 & 0,013 & 0,061 & 0,014 & 4,313 & 0,000 & 0,059 & 0,011 & 5,248 & 0,000 \\
\hline Ln BDIK1 & 0,055 & 0,036 & 1,527 & 0,135 & 0,011 & 0,017 & 0,634 & 0,529 & 0,002 & 0,013 & 0,134 & 0,894 \\
\hline Ln DPR & $-0,029$ & 0,122 & $-0,239$ & 0,812 & $-0,051$ & 0,041 & $-1,249$ & 0,219 & $-0,004$ & 0,032 & $-0,139$ & 0,889 \\
\hline $\mathrm{R}^{2}$ & \multicolumn{4}{|c|}{0,995917} & \multicolumn{4}{|c|}{0,997671} & \multicolumn{4}{|c|}{0,997989} \\
\hline Adj, $R^{2}$ & \multicolumn{4}{|c|}{0,994090} & \multicolumn{4}{|c|}{0,996628} & \multicolumn{4}{|c|}{0,997089} \\
\hline F-Statistic & \multicolumn{4}{|c|}{545,2050} & \multicolumn{4}{|c|}{957,3603} & \multicolumn{4}{|c|}{1109,066} \\
\hline $\begin{array}{l}\text { Prob (F- } \\
\text { Stat) }\end{array}$ & \multicolumn{4}{|c|}{0,000000} & \multicolumn{4}{|c|}{0,000000} & \multicolumn{4}{|c|}{0,000000} \\
\hline DW Test & \multicolumn{4}{|c|}{1,869187} & \multicolumn{4}{|c|}{1955017} & \multicolumn{4}{|c|}{1,787576} \\
\hline
\end{tabular}

katan fixed effect dengan variabel dependen LnPDRB dijelaskan oleh Tabel 6.

Berdasarkan hasil estimasi pada Tabel 6 dilakukan uji-uji untuk menentukan apakah parameter-parameter pada persamaan regresi yang terbentuk merupakan estimator yang baik. Uji-uji tersebut adalah sebagai berikut;

\section{Uji Signifikansi-F}

Uji ini digunakan untuk mengetahui apakah semua koefisien regresi variabel independen mempengaruhi variabel dependen secara bersama-sama (Widarjono, 2009). Nilai kritis F pada jumlah observasi $(\mathrm{n})=56$ dan jumlah variabel independen $(\mathrm{k})=4$ adalah 3.74 pada $a$ $=1$ persen dan 2.57 pada $\alpha=5$ persen, maka berdasarkan hasil estimasi pada tabel 6 maka disimpulkan bahwa nilai F-statistik semua model (1, 2, dan 3) berada pada daerah penolakan $\mathrm{H}_{\mathrm{o}}$ yang artinya semua variabel independen dalam model 1, 2 dan 3 dapat menjelaskan variasi dari variabel dependen secara bersamasama. Hasil ini juga sesuai dengan nilai probabalitas $F$ statistik pada ketiga model hasil perhitungan pada software Eviews versi 6 yang menunjukkan angka signifikan pada level 1 persen.

\section{Uji Signifikansi-t}

Uji signifikansi $t$ atau disebut juga uji koefisien regresi secara parsial digunakan untuk melihat apakah koefisien regresi variabel independen dapat menjelaskan perubahan variabel depen- den secara kuat (Widarjono, 2009). Hasil estimasi pada Tabel 6 menunjukkan variabel ketimpangan gender menunjukkan probabilitas yang signifikan pada level $\alpha=10$ persen $\left(G I I^{*}\right)$ dan $\alpha$ $=1$ persen $\left(G I I^{* *}\right.$ dan $\left.G I^{* * *}\right)$. Hal ini menunjukkan bahwa variabel-variabel ketimpangan gender berpengaruh kuat dan negatif (tanda koefisien negatif) terhadap variabel pertumbuhan ekonomi (Ln PDRB). Variabel belanja kesehatan (BKSH1) signifikan pada $a=1$ persen pada ketiga model yang artinya berpengaruh sangat kuat dan positif terhadap pertumbuhan ekonomi. Dua variabel independen lainnya yaitu BDIK1 dan DPR tidak menunjukkan probabilitas yang signifikan pada semua model sehingga dianggap tidak berpengaruh terhadap pertumbuhan ekonomi namun keduanya mempunyai tanda yang konsisten dengan teori.

\section{Uji Koefisien Determinasi yang Disesuaikan (Adj. R²)}

Uji ini digunakan untuk menjelaskan seberapa besar proporsi variasi variabel dependen dijelaskan oleh variabel independen (Widarjono, 2009). Dalam regresi yang menggunakan lebih dari 1 (satu) variabel dependen digunakan Adj. $R^{2}$ yang dapat mengakomodir perubahan nilai $\mathrm{R}^{2}$ ketika terjadi penambahan variabel. Berdasarkan hasil estimasi pada Tabel 6, ketiga model persamaan regresi menunjukkan nilai $A d j . R^{2} \mathrm{di}$ atas 99 persen yaitu masing-masing 99,41 persen (model 1), 99,66 (model 2) dan 99,79 persen (model 3). Nilai ini menunjukkan bahwa persamaan regresi yang dibangun oleh ketiga model 
dapat menjelaskan lebih dari 99 persen variasi dari pertumbuhan ekonomi yang diwakili oleh PDRB. Hal ini berarti model yang dibangun dalam penelitian ini cukup representatif dalam menjelaskan perbedaan pertumbuhan ekonomi.

\section{Uji Asumsi Klasik}

Penggunaan teknik regresi panel data dengan metode pembobotan white cross-section dalam penelitian ini telah mengakomodir masalah heterokedastisitas. Masalah asumsi klasik lain adalah adanya otokorelasi yang merupakan penyakit bawaan data time series. Deteksi otokorelasi dapat dilakukan dengan melihat statistik Durbin-Watson. Seluruh nilai satistik DW untuk ketiga model menunjukkan hasil bebas otokorelasi karena berada pada daerah bebas otokorelasi dengan $\mathrm{k}=4$ pada level 1 persen antara 1,55 dan 2.46 serta level 5 persen antara 1.72 dan 2.27 .

Secara umum, hasil penelitian menunjukkan bahwa adanya ketimpangan gender berpengaruh buruk terhadap pertumbuhan ekonomi. Hal ini terlihat dari penggunaan variabel indeks ketimpangan gender baik $G I^{*}, G^{* *}$, maupun $G I I^{* *}$ memperlihatkan hasil yang signifikan dan negatif mempengaruhi pertumbuhan ekonomi, artinya peningkatan ketimpangan gender akan memperlambat pertumbuhan ekonomi. Hasil penelitian ini sejalan dengan banyak studi tentang hubungan ketimpangan gender dan pertumbuhan ekonomi walaupun menggunakan variabel penjelas ketimpangan gender yang berbeda-beda, misalnya hasil penelitian Klasen dan Lamanna (2009), Baliamoune-Lutz dan McGillivray (2007), Martin dan Garvi (2005) dan Samosir dan Toersilaning$\operatorname{sih}(2004)$.

Analisis terhadap koefisien indeks ketimpangan gender pada ketiga model menunjukkan apabila terjadi peningkatan indeks ketimpangan gender $\left(G I^{*}\right)$ sebanyak 1 persen ceteris paribus, maka akan terjadi perlambatan pertumbuhan ekonomi sebesar 0,28 persen. Hal ini menunjukkan bahwa GII* merupakan indeks yang inelastis. Apabila menggunakan indikator ketimpangan GII $^{* *}$, peningkatan ketimpangan sebesar 1 persen akan memperlambat pertumbuhan ekonomi sebesar 0,067 persen. Perlam- batan pertumbuhan ekonomi sebesar 0,15 persen ketika terjadi peningkatan ketimpangan gender dengan menggunakan indikator GII***. Hal ini menunjukkan bahwa walaupun tidak elastis namun kadar elastisitas GII* lebih tinggi dibandingkan dua indeks lainnya. Artinya, GII* lebih sensitif dalam menjelaskan pertumbuhan ekonomi di provinsi Kalimantan Tengah.

Variabel belanja kesehatan sebagai proksi kebijakan pemerintah daerah dalam bidang kesehatan pada ketiga model juga menunjukkan hasil yang kuat dan positif mempengaruhi pertumbuhan ekonomi. Berdasarkan koefisien regresi dari ketiga model ini, peningkatan anggaran belanja kesehatan oleh pemerintah akan meningkatkan pertumbuhan ekonomi sekitar 0,06 persen. Variabel kebijakan pemerintah lainnya yaitu variabel belanja pendidikan menunjukkan hasil yang tidak signifikan namun konsisten dengan teori di semua model. Tidak signifikannya variabel anggaran belanja pendidikan ini diduga karena proporsi belanja pegawai yang lebih besar dibandingkan belanja pembangunannya. Di samping itu, indikator pendidikan adalah indikator yang akan memperlihatkan pengaruhnya dalam jangka panjang yang tidak terlihat dalam waktu singkat.

Variabel dependensi rasio sebagai proksi pertumbuhan populasi penduduk menunjukkan hasil yang tidak signifikan namun konsisten dengan teori. Pengaruh yang tidak signifikan ini dapat dijelaskan karena rendahnya partisipasi penduduk usia produktif dalam angkatan kerja di provinsi Kalimantan Tengah sehingga sejumlah besar penduduk usia produktif secara ekonomi kurang dapat berkontribusi terhadap pertumbuhan ekonomi.

Ketiga model persamaan dengan menggunakan variabel ketimpangan gender yang berbeda, model 3 yang menggunakan variabel GEM sebagai pendekatan menunjukkan hasil yang paling baik jika dilihat dari hasil pengujian secara statistik. Hal ini bertentangan dengan pendapat UNDP (2010) bahwa variabel GII lah yang paling komprehensif dalam menjelaskan ketimpangan gender karena lebih dalam memotret akibat ketimpangan gender dalam kehidupan perempuan. Ketidakkonsistenan ini diduga karena terdapat beberapa penyesuaian 
dalam penyusunan indikatornya yaitu tingkat fertilitas didekatkan dengan tingkat fertilitas umum yang tidak dapat menjelaskan kehilangan kesempatan para perempuan muda untuk mendapatkan pendidikan yang lebih tinggi dan pekerjaan yang layak. Selain itu, jumlah kematian ibu dalam mengkonstruksi indikator angka kematian ibu merupakan angka yang dilaporkan dan diduga jumlah kematian ibu riil lebih tinggi dibandingkan yang terlaporkan. Sebagaimana yang telah dijelaskan sebelumnya walaupun pengaruh $G I^{*}$ lebih rendah kadarnya dibanding yang lain, namun dari segi elastisitasnya menunjukkan GII* lebih sensitif dibandingkan indeks ketimpangan gender lainnya dalam menggambarkan pertumbuhan ekonomi di provinsi Kalimantan Tengah.

\section{SIMPULAN}

Hasil analisis deskriptif menunjukkan terdapat ketimpangan gender yang tajam di setiap kabupaten/kota di provinsi Kalimantan Tengah antara tahun 2004 sampai dengan 2007. Ketimpangan gender yang terjadi berkisar antara 57,878,4 persen. Wilayah yang mengalami ketimpangan gender tertajam adalah kabupaten Sukamara, kabupaten Seruyan, kabupaten Lamandau, kabupaten Murung Raya dan kabupaten Katingan dengan nilai $G I I^{*}$ di atas 69 persen.

Hasil analisis regresi data panel menunjukkan terdapat pengaruh yang negatif dan signifikan antara ketimpangan gender yang diwakili oleh 3 (tiga) jenis indeks ketimpangan yaitu GII, proksi GDI, dan proksi GEM terhadap pertumbuhan ekonomi kabupaten/kota di wilayah provinsi Kalimantan Tengah. Dari ketiga model persamaan, secara statistik ketimpangan gender yang diwakili oleh proksi dari GII tidak sekuat dibandingkan proksi dari dua indeks pembangunan gender yang lama namun hal ini diduga karena adanya penyesuaian pada indikator pembentuknya yaitu tingkat fertilitas dan tingkat pendidikan yang ditamatkan serta kurang validnya data jumlah kematian ibu sebagai pembentuk indikator angka kematian ibu. Namun, jika dilihat dari elastisitas ketiga indeks ketimpangan gender tersebut, maka GII yang diproksi dengan $G I I^{*}$ memiliki elastisitas yang lebih tinggi dibandingkan dua indeks ketimpangan gender lainnya dalam menjelaskan pertumbuhan ekonomi di Provinsi Kalimantan Tengah.

Saran. Untuk menurunkan indeks ketimpangan gender tidak lepas dari peran pemerintah dalam merencanakan kebijakan yang memprioritaskan penurunan angka kematian ibu, tingkat fertilitas serta mengupayakan peningkatan partisipasi perempuan baik dalam peran sosial maupun ekonomi. Salah satunya adalah dengan mengintegrasikan permasalahan gender dalam setiap program dan kegiatannya, termasuk didalamnya pendataan yang lebih spesifik gender dan usia sehingga perencanaan kebijakan terkait pembangunan gender menjadi lebih tepat sasaran. Bagi penelitian selanjutnya, disarankan untuk menggunakan indikator-indikator dalam dimensi Gender Inequality Index (GII) sebagai variabel penjelas pertumbuhan ekonomi agar dapat diketahui indikator mana yang paling berpengaruh sehingga dapat memberikan rekomendasi tindak lanjut kepada instansi terkait.

\section{DAFTAR PUSTAKA}

Badan Pemberdayaan Perempuan, Anak, dan KB Provinsi Kalimantan Tengah. 2009. Profil Badan Pemberdayaan Perempuan, Anak dan KB Provinsi Kalimantan Tengah, Palangka Raya.

Baliamoune-Lutz, M. dan Gillivray, M. 2007. Gender Inequality and Growth: Evidence from Sub-Sahara Africa and Arab Countries.

Insukindro, M., dan Aliman. 2001. Ekonometrika Dasar dan Penyusunan Indikator Unggulan Ekonomi. Modul. Makasar.

Kementerian Pemberdayaan Perempuan. 2011. HDI, GDI, GEM, http://www.menegpp. go.id.

Kiriti, T. dan Tisdell, C. 2003. Gender Inequality, Poverty, and Human Development in Kenya: Main Indicators. Trends and Limitations. Social Economics, Policies, 
and Development: Working Paper No. 35. University of Queensland, Australia.

Klasen, S. dan Lamanna, F. 2009. The Impact of gender Inequality in Education and Employment on Economic Growth: New Evidence for a Panel of Countries. Feminist Economist Vol. 15 No. 3, pp. 91 - 132.

Martin, R.D., dan Garvi, M.G. 2009. Gender Inequality and Economic Growth in Spain: An Exploratory Analysis. The Review of Regional Studies Vol. 39 No. 1 pp. 23 - 48.

Megawangi, R. 2005. Membiarkan Berbeda? Sudut Pandang Baru tentang Relasi Gender. Bandung: Mizan Media Utama.

Samosir, O.B., dan Toersilaningsih, R. 2004. Hubungan Kesetaraan Gender, Kemiskinan dan Pertumbuhan Ekonomi: Analisis Data Susenas 2000 dan 2002. Warta Demografi Tahun 34, No. 4, 2004, hal. 6-21.
Seguino, S. 2008. Micro-Macro Linkages between Gender, Development, and Growth: Implications for the Carribbean Region. Journal of Eastern Carribean Studies Vol. 33 No. 4 , pp. 8 - 42.

Todaro, M.P. dan Smith, S.C. 2006. Pembangunan Ekonomi (edisi kesembilan). Jakarta: Erlangga.

United Nation Development Programme. 1995. Human Development Report: Gender and Human Development. New York, USA: UNDP.

United Nation Development Programme. 2010. Human Development Report: The Real Wealth of Nations: Pathways to Human Development. New York, USA: UNDP.

Widarjono, A. 2009. Ekonometrika Pengantar dan Aplikasinya. Yogyakarta: Ekonisia. 